\title{
チベット高原における凍土融解過程の長期変動 LONG TERM VARIABILITY OF THAWING PROCESS IN THE SEASONALLY- FROZEN GROUND IN THE TIBETAN PLATEAU
}

\author{
広瀬望 1 - 小池俊雄 ${ }^{2}$ \\ Nozomu HIROSE, Toshio KOIKE \\ 1正会員 工博 科学技術振興機構（=113-8656 東京都文京区本郷7丁目 3-1） \\ 2正会員 工博 東京大学大学院工学系研究科社会基盤工学専攻（†113-8656 東京都文京区本郷7丁目3-1）
}

\begin{abstract}
To understand and predict the temporal variability of Asian summer monsoon, we should investigate the water and energy cycle in the Tibetan Plateau. Recently, air temperature observed at the meteorological station is rising because of global warming. Its warming trend is larger than that in the Northern Hemisphere. The widespread and rapid permafrost degradation is attributed to global warming. The impact of global warming affects the water and energy cycle in the Tibetan Plateau through the permafrost degradation. However, without surface hydrological observation, we can not examine the effect of permafrost degradation on the water cycle in the plateau regions. Therefore, we should investigate the trend in the thawing process by using the long term simulation results.

The objectives in this paper are to evaluate the performance of $1 \mathrm{D}$ permafrost model to simulate the thawing process in the frozen ground, to investigate the effect of soil moisture, air temperature and rainfall on the thawing process and to examine the tends in the thawing process and soil moisture in spring.

At first, the model results are good agreement with the observed data. Secondary, the model simulation indicates that the trend in the thawing process is upward, on the other hands, the trend in the soil moisture in spring is not clear.
\end{abstract}

Key Words : Thawing process in the frozen ground, Tibetan Plateau, long term variability

\section{1. はじめに}

アジアモンスーンは日本を含む，東アジアに多量の 降水をもたらすため, 長期的な水資源管理には，アジア モンスーン変動の長期予測が不可欠である. 大規模な大 気の加熱域である, チベット高原の陸面水文過程は積雪, 凍土, 土壤水分によって特徵付けられ, その年々変動や 季節内変動を通じ，アジアモンスーンの生成・維持に重 要な役割を果たす。

近年の地球温暖化によって, 高原域の多数の地上観測 点での気温は上昇傾向である ${ }^{1)}$ 。これは北半球全体より も温暖化傾向は大きい ${ }^{2)}$. 観測結果に基づいて, Wnag et al. (2000) は年平均地温が高原域で広く上昇傾向を示し, 永久凍土層の層厚が年々減少すること, また永久凍土の 季節凍土化が進行することを指摘した ${ }^{3)}$. そのため, 近 年の温暖化による凍土融解の促進が春期の土壌水分の時 空間分布変動に影響を与え，高原域の水循環を左右する ことが予想される. しかしながら, 温暖化による, 凍土 融解の進行が高原域の水循環過程に与える影響は明らか となっていない.これは高原域の長期観測データが気象
要素や地温のみであり, 地表面水文量の長期モニタリン グは行われていない.このため, GAME，CAMP，CEOPプロ ジェクトによる高原域の土壤水分観測データ取得とその 観測ネットワーク維持・強化は高原域の水循環変動把握 に非常に重要である. しかし, 観測開始から7年程度で あり，温暖化の影響把握に資する観測データは十分に蓄 積されていない. そこで，これまでのチベット高原にお ける水文観測結果から, 凍土融解の物理プロセスの理解 とそのモデル化を行い，モデルを用いて，凍土融解過程 の長期変動を検討する必要がある.

チベット高原における凍土の水文過程に関して，観測 結果に基づいて, Ohta et al (1994)や矢吹ら(1998)は土壤 水分量の乾湿差が凍土の融解速度と密接に関係すること を示した4), 5)。また，広瀬ら(2004)は観測結果に基づいて， 凍土融解過程は土壤水分の不均一性形成プロセスに重要 な役割を果たすことを明らかにした6). 具体的には下記 のプロセスである. 平坦地における土壤水分分布形成は 領域内に存在する微小な地形のうねり, つまり微地形起 伏が形成する土壤水分の乾湿偏差が端緒である. 微地形 起伏による凹凸が春期の融雪水や降水による水分を分配 し, 凹地では水分が貯留することによって, 土壌水分が 
相対的に大きくなる. 一方, 凸地では水分が貯留せず, 相対的に低い土壤水分となり，微地形起伏に応じた土畩 水分の乾湿偏差が形成される. さらに凍土の融解過程と 土壌水分との相互作用により, 乾湿偏差が助長される.

このような土壤水分の不均一性は陸面からの領域平均 水・熱フラックス算定に大きな影響を与える゙．そのた め, 春期加夏期における大気一陸面相互作用を理解寸 るためには, 凍土融解の変動把握は不可欠である.

チベット高原における凍土融解過程のモデル化に関し て, 先行研究を概観する. まず凍土融解の長期変動に着 目し，数值モデルを用いて， Oelke et al. (2005) は長 期シミュレーションを行い, 高原スケールでの凍土融解 分布を推定した. そして, 温暖化によって気温が正の卜 レンドを示すことと対応し, 高原北部の凍土融解深が 年々深くなることを示した ${ }^{8}$. しかし，このモデルは水分 移動を考慮せず，熱移動モデルに水の相変化が組み込ま れたもので, 土壌水分などの地表面水文量変動が考慮さ れていない，また，観測結果を用いた検証は行われてい ない，そのため，チベット高原は永久凍土と季節凍土が 広く混在する状況にもかかわらず，永久凍土のみしか考 慮されていない。

一方，高原域のポイントスケールの観測結果を用いて， Li and Koike(2003) は陸面過程モデル(Sib2)に簡易な凍 土融解のパラメタリゼイション手法を導入し，その再現 性を検討した ${ }^{9}$ ．簡易な推定が可能なため，有用である。 しかし, 凍土融解過程を考える上で重要な, 土壌水分の 乾湿差による凍土融解速度の変化が考慮できない，した がって, 水・熱移動を詳細な記述したモデルを用いて, 高原域の凍土融解過程の再現性を検討寸る必要がある. そのため, 本論文は次の3点を目的とする.

1) 観測結果に基づいて, 凍土域での水・熱移動を記述で きる凍土一次元モデルを同定し，土壤水分・地温と凍 土融解の季節変化に関し，モデルの再現性を検討する. 2) 同定したモデルを用いて, 初期土壌水分量, 気温, 降 水に対する，モデルの応答特性を明らかにする.

3) 再解析データを用いて，長期シミュレーションを行い, 凍土融解の長期変動を明らかにし, その変動と土㙵水 分や蒸発量との関係を検討する.

本研究で得られた成果は水・熱移動を詳細に記述する 凍土一次元モデルを用いて, 凍土融解の再現性を示した 点で有用である. また，モデルを用いて，凍土融解の長 期変動特性把握と, 春期の土袞水分との関係を明らかに した点において，チベット高原域の水循環変動理解に資 する研究と位置付けられる.

\section{2. モデルの概略}

これまでチベット高原の観測結果に基づいて，凍土の 物理過程を考慮した凍土一次元モデルの開発や検証が行
われてきた ${ }^{7), 10)}$. 本研究はこのモデルを用いて, 解析を 進めることとした．モデルの概略は以下のとおりである.

凍土一次元モデルは鉛直一次元の水・熱移動を物理式 に基づいて記述する. このモデルの特徵は水輸送計算を 規定する土壌の層区分と独立して, 凍結境界面が決定で きることである. モデルの詳細は以下の通りである.

熱輸送の取り扱いは気象要素(放射収支，気温，気圧， 風速, 湿度, 降水)を入力とし, 地表面熱収支計算に基 づき，地表面温度を算出する，そして推定した地表面温 度と最深部の地温 $(6 \mathrm{~m})$ を境界条件とし, 土壌中の熱伝導 計算により，各時間ステップの地温の鉛直プロファイル を求める. また水輸送はRichards方程式を基礎とし, 層 モデルで土壌水分の鉛直プロファイルを計算する，なお， 本研究は1) 土層の分割を5層から6層に変更し，2) Chen et al (1998) の研究成果 ${ }^{11)}$ 加, 土㙵中の水の生成量推 定法をモデルに導入し，モデルに二つの修正を加えた.

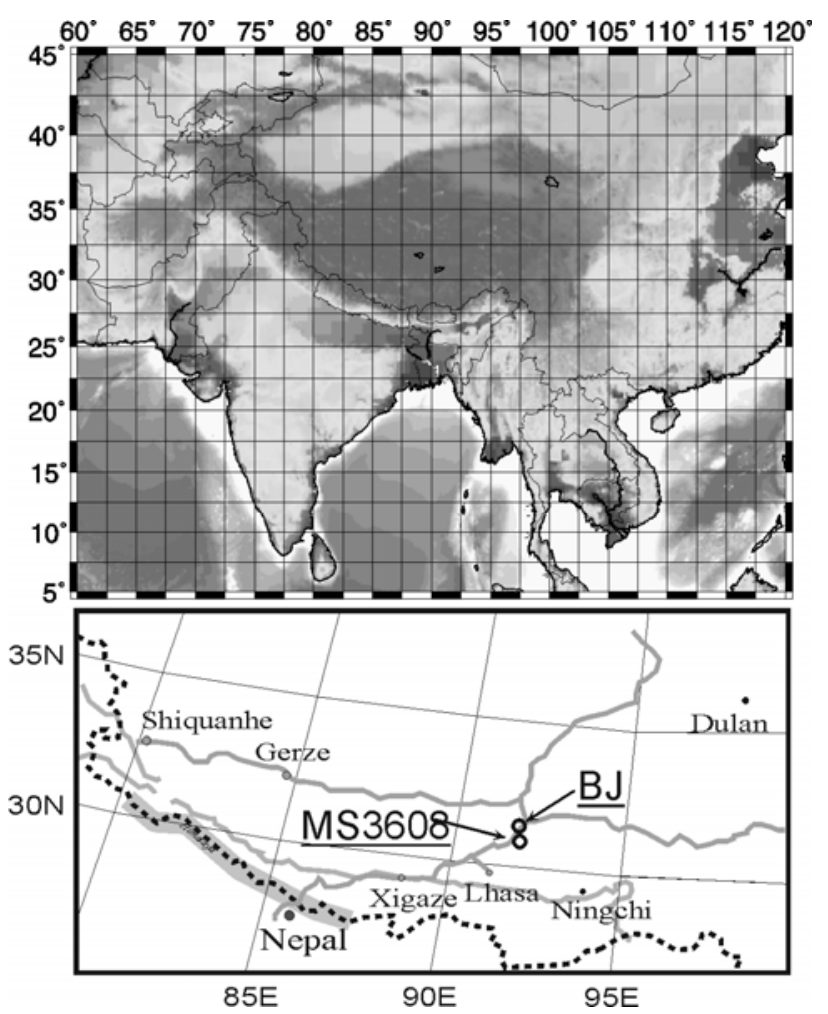

図-1 観測地点 (BJ, MS3608) の位置図

\section{3. モデルパラメータの同定}

\section{（1）使用データについて}

凍土一次元モデルを適用寸るため, モデルの土袞物理 パラメータ推定が不可欠である. 本研究はチベット高原 のほぼ中央に位置する, BJ地点（北緯31.368度，東経 091.898度, 標高4510m, 図-1参照) で得られた観測デー タを用い，モデルの土壤パラメータを同定した。

\section{（2）モデルの同定結果}

モデルの再現性を検討するために, 土壌水分と地温プ 
ロファイルと，凍土融解深の季節変化の3つに着目し， モデルの計算結果と観測結果との比較を行った.

まず土壌水分プロファイルの再現性を検討する。図一 2aはモデル第1層から第6層までの各層と， $4 \mathrm{~cm}, 20 \mathrm{~cm}$, $60 \mathrm{~cm}, 100 \mathrm{~cm}, 160 \mathrm{~cm}, 210 \mathrm{~cm}$ 深さの観測結果との最 小二乗誤差(RMSE)を示した．各層のRMSE は3-4\%であ り, よく一致しているものの, モデル第5層のみ大きく 異なる結果となった。これは鉛直の水分移動プロセスの みで表現できないため，側方流出や地下水の影響である と考えられる.

次に，地温プロファイルの再現性を検討した。図-2b は各深度におけるRMESの計算結果である。また，図-3 は凍土の融解深の季節変化の比較を示した，表層付近は RMSEが大きいものの, 凍土融解深さの季節変化をモデ ルがよく再現した.
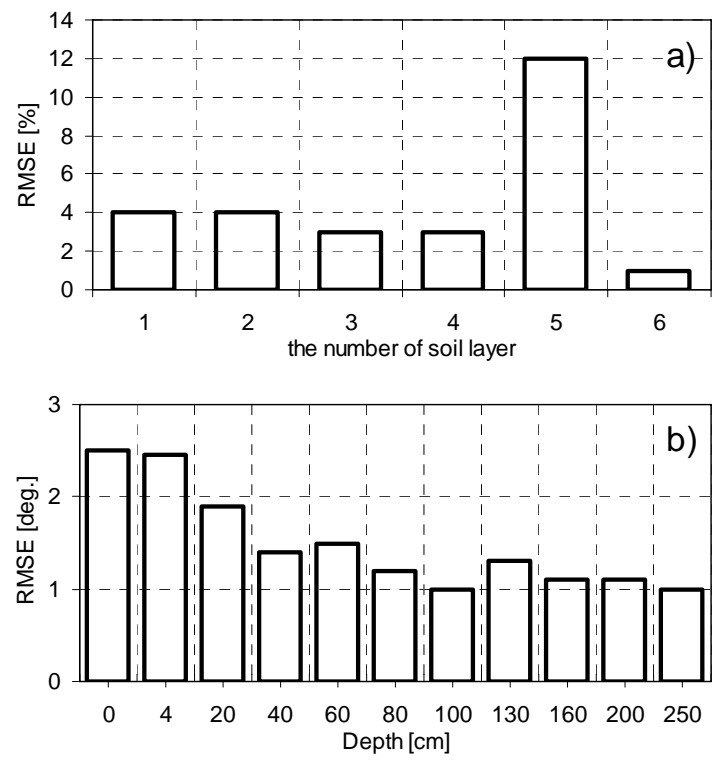

図-2 a)土袞水分とb)地温プロファイルのRMSEの結果

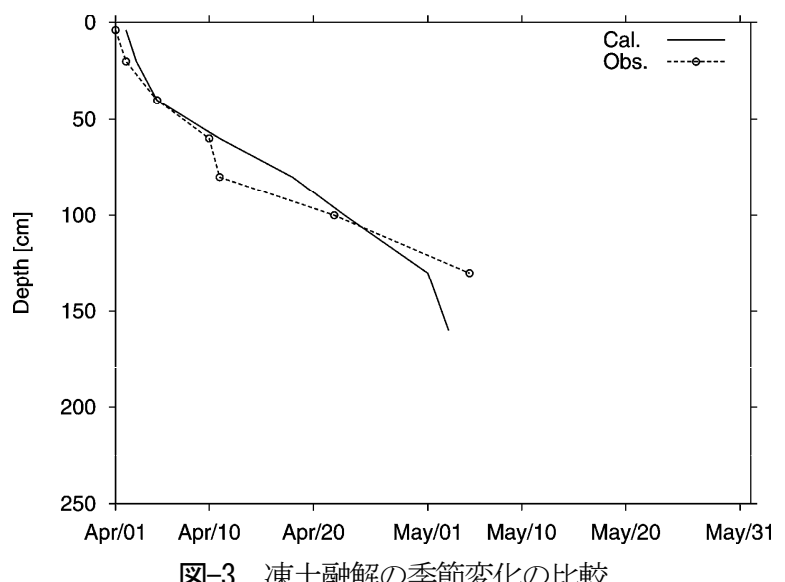

\section{4. モデルの応答特性}

モデルによる凍土融解過程を理解する上で，境界条件 や入力条件に対する，モデルの応答特性把握が不可欠で
ある．本章は初期土壊水分，気温，降水に着目し，それ ぞれの変化に対して，凍土融解がどのように変化するか に着目し，検討することとした。

\section{(1) 初期土壌水分}

初期条件となる土壌水分量を5\%，10\%，20\%で，その鉛 直プロファイルを一様とし，モデル計算を行い，土壌水 分の乾湿が凍土融解の進行に与える影響を検討した.

図-4は3つの土畩水分の初期条件に対する，凍土融解深 の季節変化を示した。図に示すように，初期土䁃水分が 大きくなると, 含水量が大きくなるため, 融解に必要な 熱量が多くなるため, 融解が遅くなる様子が示された.

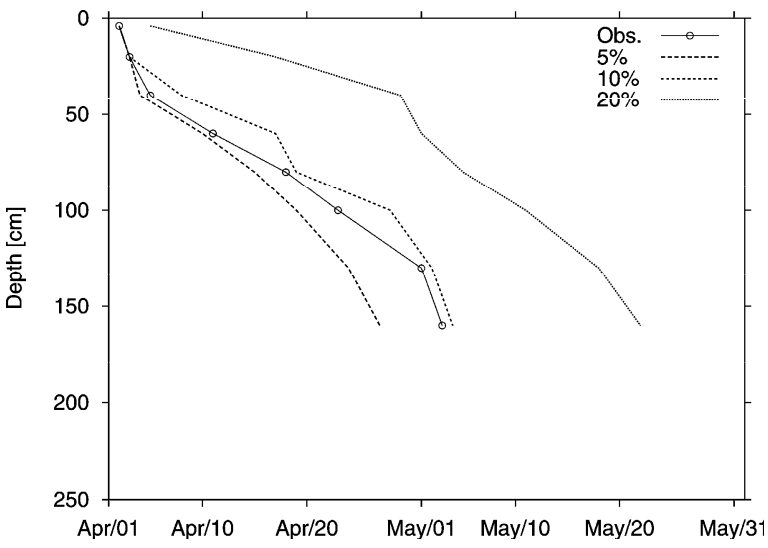

図-4 初期土壌水分の違いに対寸る, 凍土融解深の比較

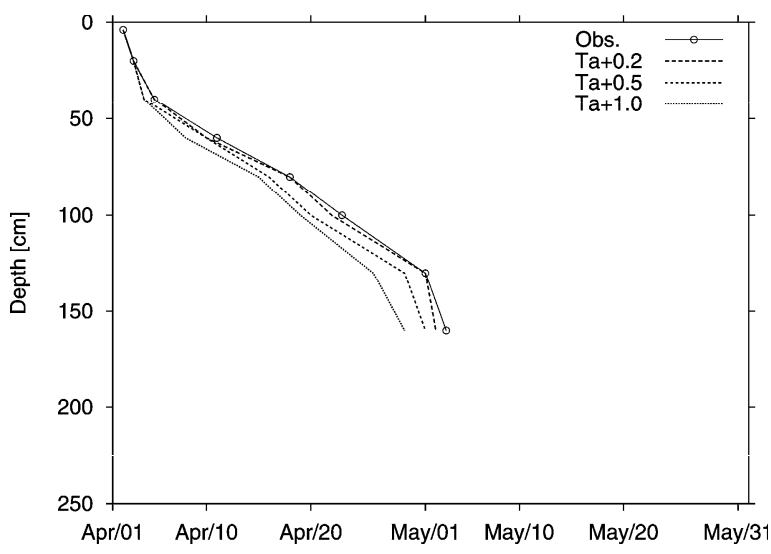

図-5 気温変化に対寸る，凍土融解深の季節変化の比較

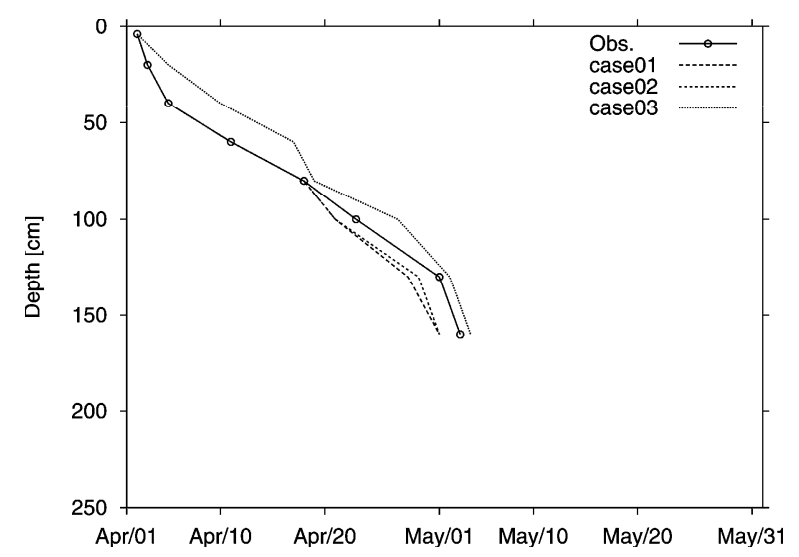

図-6 降水の与え方の違いによる, 凍土融解深の比較 


\section{(2) 気温}

温暖化による気温上昇は凍土融解を早める。そこで， 気温に $0.2^{\circ} \mathrm{C}, 0.5^{\circ} \mathrm{C}, 1.0^{\circ} \mathrm{C}$ と加えて, 計算を行った. 図-5は異なる気温条件での凍土融解深の季節変化を示し た. 図に示しように，気温が高くなると，積算暖度が上 昇し, 凍土融解が早くなることが示された.

\section{（3）降水}

降水強度と降水パターンによって, 凍土はどのような 影響を受けるのかを明らかにする。降水強度に関しては， 単純に降水強度を大きくし，その応答特性を図に示した。 また，降水の与え方による影響を見るために，観測降水 量からPentadの積算降水量を求め，5日間に1回の降水が ある場 (case01)，1日1回の降水がある場合 (case02), 毎時間降水が続く場合 (case03) の3つのケースで融解深 の変化を検討した(図-6. 与え方によって大きな違いは ないものの, case03は観測結果のシミュレーションに近 く, 降水回数が減る (case01) と, 融解が早まる.これは 降水回数の減少が土壤水分を減少させ, 蒸発量が小さく なることによって，地温が上昇するためである．一方， 降水強度は2倍にした場合, その差が大きくなる。

\section{5. 凍土の長期シミュレーション}

(1) データ

ECWMFの再解析データ (ERA40) と降水量データ (GPCP)を用い，モデルの長期シミュレーションを行う. 対象期間は1979年から2002年の各年4月から9月で，対象 地点(BJ)に最も近いグリッドデータを計算に用いた.

Frauenfeldra(2005)はチベット高原域の気象観測点デー タを比較し，ERA40の地上 $2 \mathrm{~m}$ 気温データは過小評価で あるものの, 観測結果との相関が高く, 経年変動をよく 捕らえていると指摘した ${ }^{12}$. そのため, ERA40をモデル の入力データとした．なお，ERA40の短波放射は観測 結果より小さいため, 係数を乗じ, 補正した. 一方, 他 の気象要素はそのまま使用した.

\section{（2）初期条件について}

1979年から2002年の各年4月における，モデルの初期 条件（土壤水分と地温の鉛直プロファイル）を用意する 必要がある. 土壌水分プロファイルは，まず1979年の初 期值を $5 \% ， 10 \% ， 15 \%$ と一様と仮定し，1979年から2002 年まで計算を行う．次に，3つのケースの2002年9月の土 壌水分プロファイルを平均し，1979年の初期条件とした (図-7a).また1980年以降は前年9月のプロファイルを次 年の初期条件とした。一方, 地温プロファイルはBJ地点 の4月の平均プロファイルを求め, その結果を初期值と し，毎年同一の值を使用した(図-7b).

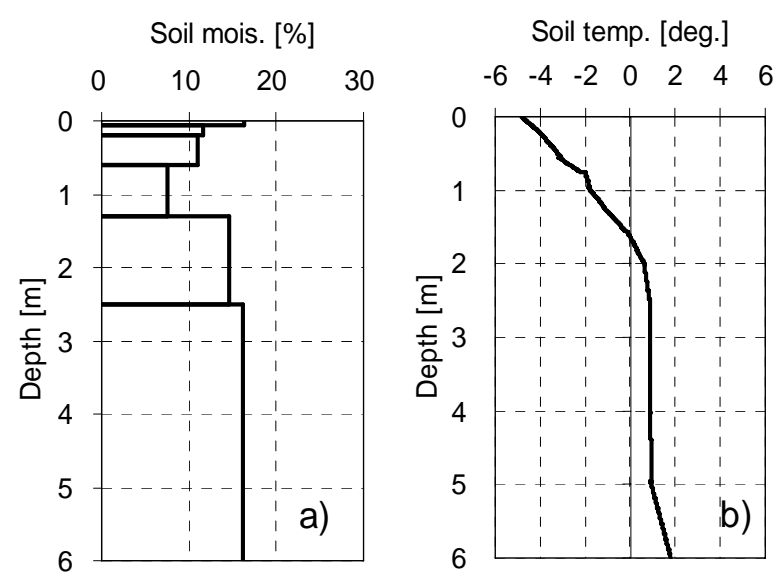

図-7 モデルの初期条件

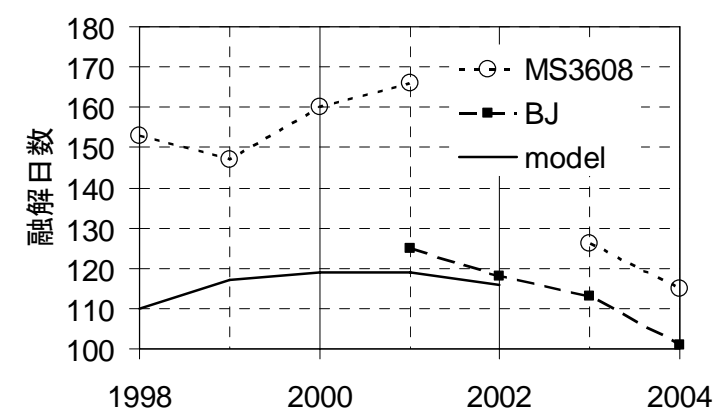

図-8 凍土融解に関する, 長期シミュレーション結果と観測 結果との比較. 実線が計算結果, 丸印+点線がMS3608の観測 結果, 黒四角+破線がBJ地点での観測結果
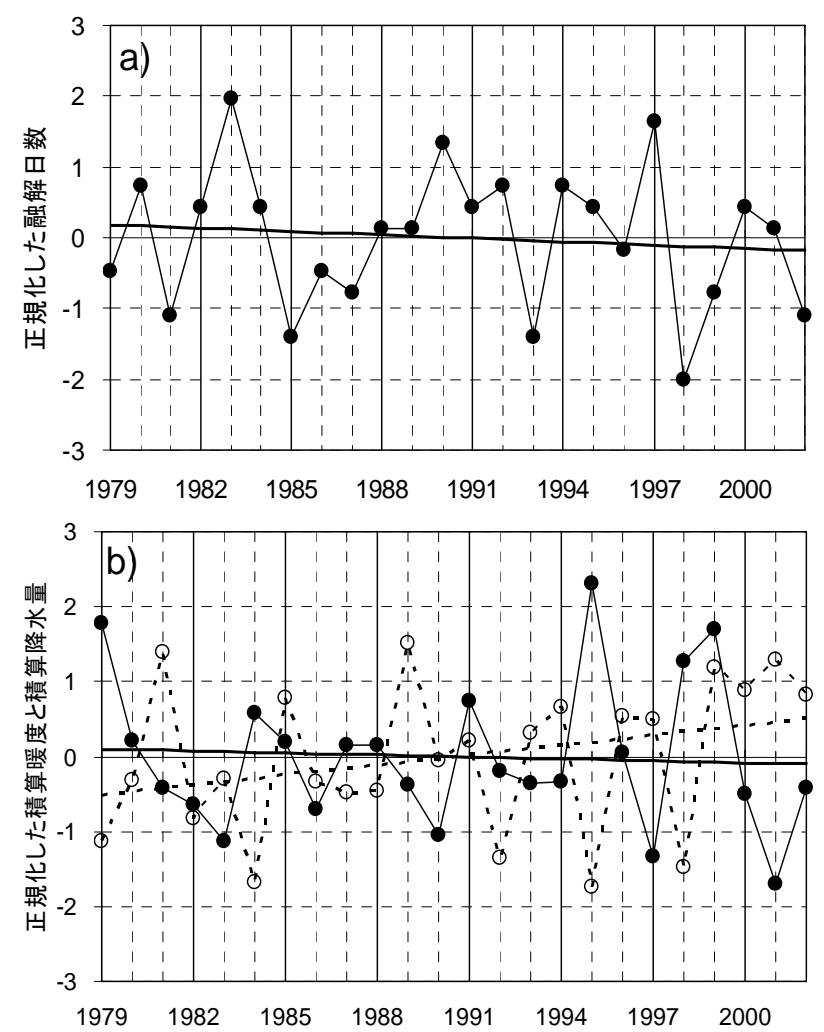

図-9 a) 凍土融解，b) 積算暖度 (黒丸と実線) と積算降水量(白 丸と点線) の長期変動 


\section{（3）観測結果との比較}

まず，凍土融解の長期変動を検討するために，モデル の計算結果が観測結果と同様の傾向を示すことを確認す る必要がある. BJ地点は季節凍土域であり, 深さ $130 \mathrm{~cm}$ 程度が涷結最深部である，そのため，この深度が融解に 要した日数を1月1日から積算し, 融解日数と定義した.

図-8は融解日数の計算結果と観測結果の比較を示した。 BJ地点は2001年以降しか比較できないため，BJ地点に近 く, 長期の観測データがあるMS3608地点(図-1参照)の結 果も図示した. モデルは観測結果の傾向を比較的よく再 現した.

\section{（4）長期トレンド}

\section{a) 凍土融解過程}

次に凍土融解の長期変動特性を検討寸る．図-9aは融 解日数を正規化し, 凍土融解の長期変動を示したもので ある. 凍土融解の長期トレンドは有意ではなく, その 年々変動は大きい

次に，モデルの入力条件である，ERA40の地上 $2 \mathrm{~m} の$ 気温とGPCPの降水量の長期トレンドを調べた。地上気 温に関して，凍土融解の影響を知るため，1979年から 2002年までの4月から6月の期間における積算暖度を算出 した. 同様に，GPCPの降水量に関しても，同期間におけ る積算降水量を算出し, 検討した. 図-9bは正規化した 積算暖度と積算降水量の長期変動とそのトレンドを示し た．両者の長期トレンドは有意でない．また積算暖度や 積算降水量の年々変動は大きく, 特に積算暖度は1994年 以降, その変動幅が増加傾向である.

\section{b）春期の土壤水分変動の長期トレンド}

次に, 凍土融解の長期変動が土壤水分変動と, どのよ うな関係にあるのかを検討した．融解期における土壤水 分変動を検討寸るため, 5月の平均土畩水分に着目し, 表層から $60 \mathrm{~cm}$ ま゙の土壤水分プロファイルから水分量 $(\mathrm{mm})$ に換算した．その結果，5月における $60 \mathrm{~cm}$ までの土 壌水分の長期トレンドは明瞭ではなかった (図-10).

\section{c）春期の積算蒸発量の長期トレンド}

凍土融解の長期変動が土袞水分を通じ, 蒸発量に影響 を与えることが予想されるため, 蒝発量の長期変動を検 討した. 図-11は正規化した5月の積算蒸発量の長期変動 を示した. 図に示すように, 積算蒸発量の長期トレンド は明瞭でなく，年々変動が大きい傾向がある.

\section{（5）年々変動の理解}

（4）で検討したように，凍土融解，土壤水分量，積算 蒸発量の年々変動は大きい，そこで，この年々変動の要 因を検討する４章で得られた知見より，凍土融解の 年々変動は土壤水分や気温の影響を強く受けると予想さ れる. そこで, 凍土融解過程の年々変動々, 土壤水分, 気温，降水の変動との相関を検討した.

図-12は凍土融解と5月の土壤水分量の変動に対寸る,
各水文量との相関係数の比較した. 両側5\%の有意水準を 超える相関は初期土畩水分と積算暖度であり，比較的相 関が高い. 一方, 積算降水量や積算蒸発量との相関は低 い. 特に, 積算蒸発量については, 湿度変動などの他の 気象要素の影響を強く受けるため, 凍土融解と相関は小 さかったと考えられる. しかし, 積算暖度, 積算降水量, 積算蒸発量と土㙥水分量との相関は高く, 有意であった. そのため, 前年の降水変動や蒸発量の影響を受けた，初 期土猿水分の年々変動が凍土の融解速度の速さを大きく 左右し，さらに，気温变動が凍土融解開始時期に影響を 与えると考えられる。

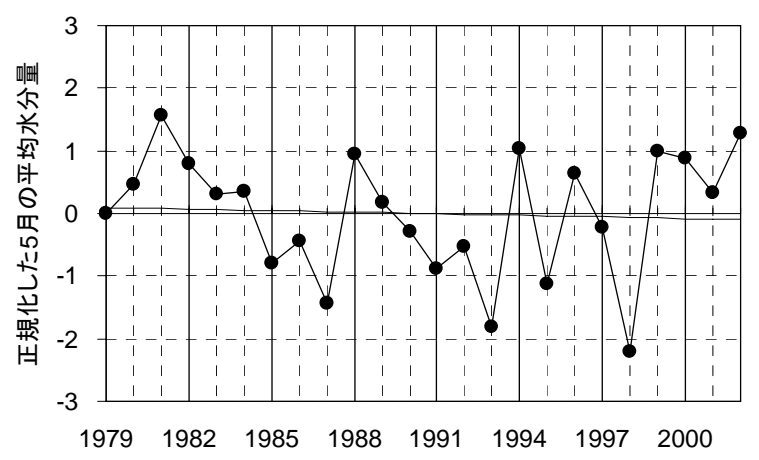

図-10 5月の平均土壤水分の長期変動

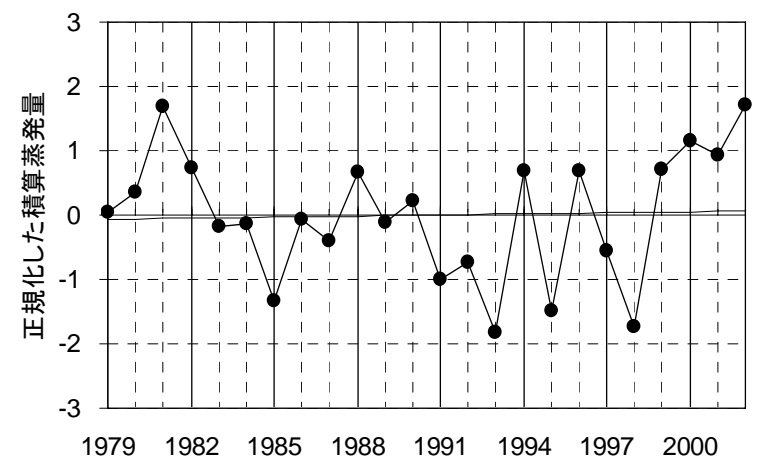

図-11 正規化した積算蒸発量（4月-5月）の長期変動

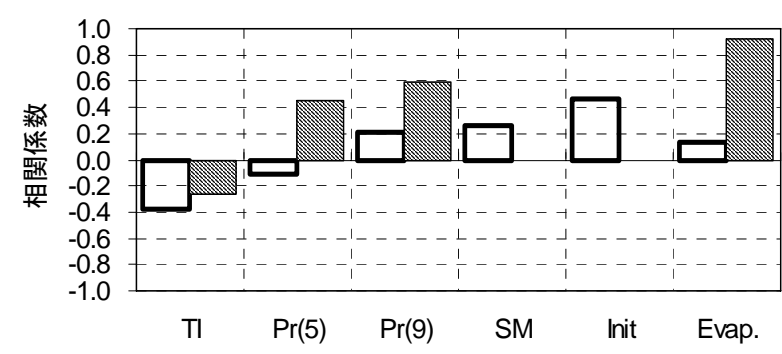

口凍土融解口土境水分(SM)

図-12 凍土融解(白抜き) と5月の土壤水分変動(斜線)に対する, 積算暖度（TI），5月までの積算降水量 $(\operatorname{Pr}(5)) ， 9$ 月までの積算 降水量 $(\operatorname{Pr}(9)), 5$ 月の土袞水分量 (SM), 初期土壌水分量 (Init), 積算蒸発量(Evap.) との相関係数の比較.

\section{6. まとめと今後の課題}

本研究は水・熱移動を考慮した凍土一次元モデルを用 
いて, 凍土融解の長期変動と, 春期の土䁃水分や蒸発量 の長期変動を明らかにした，具体的には次の4点である。

（1）モデルを用いて，凍土の融解過程を再現した.

(2) モデルの感度実験を行い，土壌水分，気温変動，降 水パターンの影響を明らかにした．特に土壤水分の乾湿 偏差は凍土融解速度と関係し，土畩水分が湿潤であれば 融解が遅く, 乾燥傾向であれば融解速度は速い. これは 観測から得られた知見と一致する.

（3）長期再解析データを用いて，凍土融解，春期の土畩 水分と蒸発量の長期トレンドを明らかにした。その結果， 凍土融解の長期トレンドは明瞭でなく, その変動が大き いことがわかった．また，春期の土壤水分変動の長期卜 レンドはほとんど見られなかった。 これは，モデルの入 カデータの影響であると考えられる.

(4) 凍土融解と土壌水分の年々変動と, 各水文量 (積算暖 度, 積算降水量, 土畩水分量, 積算蒸発量)の相関を検 討した. その結果, 土壤水分の初期值と積算暖度との相 関は高く，両側5\%の有意水準を満たす。一方，積算降水 量や積算蒸発量との相関は低かった。

今後はモデルの入力データを検討するとともに，通年 でのモデルシミュレーションが行えるよう，積雪を考慮 したモデル化が課題である.

チベット高原における冬期水文量変動に関して，Sato （2001）は1993-1999年の気象観測所のroutineデータを用 いて，高原域の積雪と凍土の実態を報告した ${ }^{13)}$. また， Ueno et al (2005)は2004年冬期に高原域の南北方向に観 測を行い，スナップショットではあるものの，南北方向 の積雪深分布，積雪密度や積雪の層構造を明らかにした 14)。一般的な平年状態では，高原域の積雪深は $10 \mathrm{~cm}$ 程度 と薄く，100m以下のローカルスケールでPatch状に分布 する，観測的知見から，薄い積雪ではあるものの，降雪 強度やその時期によって, 積雪の水文学的効果 ${ }^{15)}$ も考え られ，通年のシミュレーションを目指し，高原域におけ る積雪の物理過程把握やモデル化に取り組む必要がある.

謝辞：本研究は科学技術振興事業団戦略的創造研究(水 循環系の物理的ダウンスケーリング手法の開発), 科学 振興調整費 (地球水循環インフォマティクスの確立), 統 合地球水循環強化観測期間プロジェクト (CEOP) の研究成 果の一部である. 記して深く謝意を表す。

\section{参考文献}

1) Liu $X D$, Chen BD: Climatic warming in the Tibetan Plateau during recent decades, INTERNATIONAL JOURNAL OF CLIMATOLOGY, 20, 1729-1742, 2000.

2）安成哲三:チベット高原での大気陸面相互作用とアジアモン スーン, モンスーン研究の最前線, 気象研究ノート, 204, 99-114, 2003.

3) Wang SL, Jin HJ, Li SX, Zhao L: Permafrost degradation on the Qinghai-Tibet Plateau and its environmental impacts,
PERMAFROST AND PERIGLACIAL PROCESSES 11 (1): 4353, 2000.

4) Ohta T, H. Yabuki, T. Koike, T. Ohata, M. Koike and Y. Zhang: Hydrological observations in the Tanggula Mountains, the Tibetan Plateau - discharge, soil moisture and ground temperature-, Bulletin of Glacier Research, 12, 49-56, 1994.

5）矢吹裕伯, 大畑哲夫, 上田豊 : チベット高原凍土地帯の地 表層過程の季節変化, 1. 地表層の水分 - 熱的状態, 水文 · 水資源学会誌，11，324-335，1998.

6）広瀬望，小池俊雄 : チベット高原における土壤水分分布の 微地形依存性，水工学論文集，Vol48，pp205-210，2004.

7) Nozomu Hirose, Koike Toshio and Ishidaira Hiroshi: Study on Spatially Averaged Evaporation under Soil Moisture Heterogeneity Affected by Permafrost Micro-topography, JMSJ, Vol.80, pp191203, 2002.

8) Oelke, C. and Zhang, T.: Modeled Changes in Active-Layer Depth over the Tibetan Plateau, First CliC International Science Conference, Beijing, P.R. China, 11-15 April 2005, Book of Abstracts, p. 199, 2005.

9) Li X, Koike T: Frozen soil parameterization in SiB2 and its validation with GAME-Tibet observations, COLD REGIONS SCIENCE AND TECHNOLOGY, 36, 165-182, 2003.

10) Ishidaira, H., T. Koike, M. Lu and N. Hirose: Development of distributed hydrological model for permafrost regions considering 1$\mathrm{D}$ heat and water transfer and river flow processes, Proceedings of $7^{\text {th }}$ International Permafrost Conference, Yellowknife, Canada, 501508, 1998.

11) Chen, X., T. Mituno, H., Horino and T. Maruyama: Numerical Experiment Method of the Soil Freezing and Thawing Process by Coupled Heat and Water Transfer Model, Studied on the analysis of the freezing and thawing process of soils(1), Soil Phys. Cond. Plant Growth. Jpn, 78, 25-34, 1998.

12) Frauenfeld OW, Zhang TJ, Serreze MC: Climate change and variability using European Centre for Medium-Range Weather Forecasts reanalysis (ERA-40) temperatures on the Tibetan Plateau, JOURNAL OF GEOPHYSICAL RESEARCH-ATMOSPHERES 110 (D2): Art. No. D02101, 2005.

13) Sato, T: Spatial and Temporal variation of Frozen Ground and Snow Cover in the Eastern Part of the Tibetan Plateau, JSMJ, Vol.79, 510-534, 2001.

14) UENO K, Kenji TANAKA, Hiroyuki TSUTSUI, and Maoshan LI (2005), Water cycle conditions in the Tibetan Plateau observed in 2003/04 winter, Arctic, Antarctic, and Alpine Research, Submitted.

15) Yasunari, T, Kitoh, A and Tokioka, T: Local and remote responses to excessive snow mass over Eurasia appearing in the northern spring and summer climate- A study with the MRI GCM, JMSJ, 69, 473-487, 1991.

(2005. 9. 30受付) 